\title{
DAVENPORT WOMAN IN THE WHITE HOUSE
}

\author{
Taken from the Davenport Democrat \\ Sunday Newspaper of April 24, 1938
}

The following was written by Ralph W. Cram as a part of a series of articles of reminiscence written for the Davenport Democrat, the newspaper of which Mr. Cram was editor.

I had a friend in the White House for 17 years. Not the president, of course-none ever stayed that long. The friend was a lady-not the First Lady-she stays only as long as her husband. In her way, none the less, this friend was first lady in her special domain in the executive mansion, under Presidents Taft, Wilson, Harding and Coolidge. As its housekeeper she ran the White House to the satisfaction of three presidents and with the interference of the fourth, until she re signed in 1927, and wrote a book about it.

Mrs. Elizabeth Jaffray had lived in Davenport for a number of years-she and her husband prominent in social and church circles, until the death of her husband threw her upon her own resources. "I had to earn my own living," she wrote afterward. "For two or three years I superintended a house of half a dozen servants and then for a year I acted as a social secretary in New York."

ses

Then opportunity knocked at her door.

\section{Is Offered an Unusual Position}

It was in December, 1908, toward the end of the Roosevelt administration, that Mrs. Jaffray was called to an exclusive employment bureau in New York and told by its head: "I think I have the most unusual position in the world for you-and I think you are the one person I know who can fill it. It is to take over the full management of the White House for Mr. and Mrs. Taft." 
Mrs. Jaffray thought she couldn't possibly do it. It looked like too big a job. Ultimately, in an interview with Mrs. Taft, she was prevailed upon to try the post for three months to see how it would work out. She stayed for 17 years.

When she wrote about it for Cosmopolitan Magazine, she put down in short sentences her most vivid impressions of the four presidents and their ladies whom she had known so intimately.

\section{Mrs. Harding Had Loveliest Clothes}

Taft was the best natured president, Wilson the kindest, Harding the best-dressed, Coolidge saved the most money. Mrs. Taft was the tiniest first lady, the first Mrs. Wilson the most motherly, the second the most affectionate, Mrs. Harding had the loveliest clothes, Mrs. Coolidge was "ostensibly the happiest."

President Taft had steak for breakfast-12 ounces of it until "he weighs 332 pounds and tells me with a great laugh that he is going on a diet." Later his doctor put him on one, and cut the breakfast steak to six ounces.

Her respect and love for President Wilson were "unbounded," but the last year and a half he was in the White House "he was no more himself mentally than he was physically." She was able to make of record many important details of Mr. Wilson's last illness, all set down with good taste and judgment. "Mrs. Wilson was certainly the assistant president of the United States." Of her own part in the White House Mrs. Jaffray wrote that she thinks she was "happiest in those years of the second Mrs. Wilson before the President was taken ill."

\section{Toothpicks Appear on White House Table}

Then came the Harding administration, of which Mrs. Jaffray was silent about poker, galluses and grafting friends. 
Mr. Harding was a very human person. He liked to assemble 12 or 15 men at private dinners. Often he pleaded that sauerkraut and wieners be the piece de resistance, so the cook was ordered to prepare them. He was partial to corn bread, muffins and pie. He also insisted on toothpicks being added to the table furnishings, for the first time in how long Mrs. Jaffray evidently did not attempt to guess.

\section{Cautious Cal Counts the Hams}

President Coolidge was the first to direct that the daily menus at the White House be submitted to him. He was silent and austere, in contrast with "the jolly Mr. Taft, amiable Mr. Wilson and kindly Mr. Harding." Mrs. Jaffray recalled few conversations with Mr. Coolidge. The one most vividly remembered concerned the fact that six hams-the small Virginia hams-had been prepared in the kitchen for a dinner of 60 people. It seemed an awful lot of ham to the President, and "there was no need to argue so I left the room."

So one did not need to wonder why Mrs. Jaffray left the White House during the Coolidge administration. Her magazine articles made good local news in Davenport so I seized the opportunity to sumarize them and pass her salty comment on to her Davenport friends. They had known and liked her during her years of life out here on the bank of the Mississippi. Back in the early 1900's, neither she nor they had imagined that 17 of her later years would be spent in close intimacy with four presidents and their families. 
Copyright of Annals of Iowa is the property of State of Iowa, by \& through the State Historical Society of Iowa and its content may not be copied or emailed to multiple sites or posted to a listserv without the copyright holder's express written permission. However, users may print, download, or email articles for individual use. 